\title{
A GEOGRAFIA DAS IMAGENS: discutindo o espaço público no filme de Eric Rohmer
}

- ALICE NATARAJA GARCIA SANTOS

\section{RESUMO}

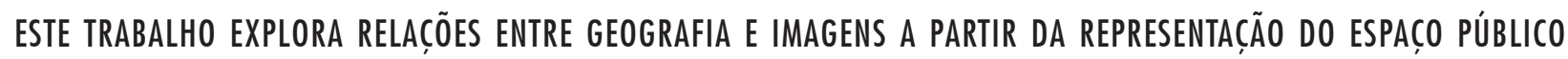
NO CINEMA. COM TAL OBJETIVO, SELECIONAMOS A OBRA DE ERIC ROHMER, UM AUTOR E DIRETOR DE CINEMA FRANCÊS QUE VALORIZA A DIMENSÃO ESPACIAL NO CINEMA. NO PRESENTE ARTIGO ANALISAMOS SEU PRIMEIRO LONGA-METRAGEM,

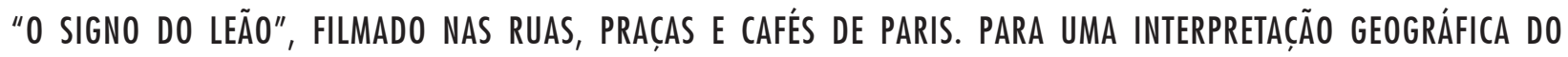
FILME, UtILIZAMOS COMO FERRAMENTA 0 CONCEITO DE ESPAÇO PÚBLICO. TRATA-SE DE UMA IMPORTANTE FERRAMENTA

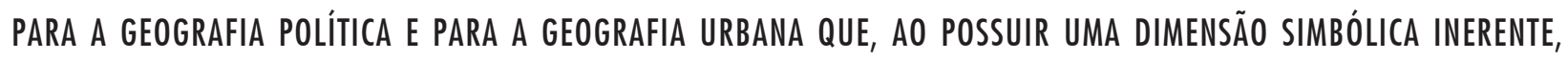
TEM MUITO A CONTRIBUIR PARA UMA GEOGRAFIA CULTURAL QUE SE DEBRUÇA SOBRE 0 UNIVERSO URBANO DE MANEIRA INTERPRETATIVA. O ESFORÇO AQUI NÃO É ENCONTRAR UMA MENSAGEM PRÉ-EXISTENTE NO FILME, MAS INTERPRETÁ-LO SOB A PERSPECTIVA dO CINEMA COMO MEIO QUE DIZ RESPEITO NÃO APENAS A UMA MANEIRA DE ENTENDER 0 MUNDO, COMO A UMA CONCEPÇ̃̃O SOBRE A DIMENSÃO ESPACIAL DA VIDA URBANA.

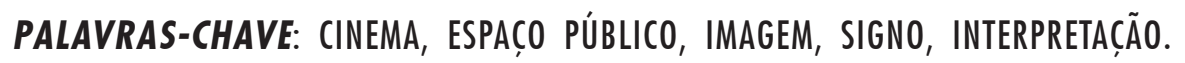

INTRODUÇÃO

Este trabalho, fundamentando-se nos teóricos da chamada Nova Geografia Cultural, busca explorar as relações entre geografia e imagens a partir das representações do espaço público no cinema. Com tal objetivo, selecionamos o trabalho de um autor e diretor de cinema francês, cuja vasta carreira e vasta bibliografia nos interessavam particularmente, por possuírem uma temática recorrente que valoriza a dimensão espacial no cinema. No presente trabalho, selecionamos o filme "O signo do leão" - seu primeiro longa metragem di- rigido no ano de 1959 - rodado em pleno clima de surgimento da Nouvelle Vague, importante movimento do cinema francês do qual é um dos filmes fundadores.

Temos como objetivo geral o de investigar em que medida o espaço participa da construção do filme. Como objetivo específico, buscaremos, através do uso de métodos de análise de outras disciplinas que incorporam a semiologia - como a antropologia e a sociologia da arte - proceder a uma leitura da imagem como signo. Utilizaremos como ferramenta para a sua interpretação geográfica o 
conceito de espaço público. Trata-se de um importante conceito para a Geografia política e para a Geografia urbana que, por possuir uma inerente dimensão simbólica, tem muito a contribuir para uma geografia cultural que se debruce sobre o universo urbano e suas representações de maneira interpretativa

O texto seguirá divido em três partes. Na primeira, nos fundamentamos nas discussões conceituais e metodológicas trazidas pela Nova Geografia Cultural bem como pela linha da semiologia francesa que lida com imagens. Na segunda parte, apresentamos uma contextualização sobre o período de surgimento da obra, que marca tanto seu criador como seu público receptor. Finalmente, na terceira parte, procuramos estabelecer um diálogo entre as diferentes proposições teóricas e metodológicas apresentadas, a partir da criação de um ponto de vista geográfico sobre essas imagens aqui descritas. Lançamo-nos na análise das imagens, em função de uma pré-seleção criteriosa daquelas que nos ofereciam maiores possibilidades de levantar a discussão espacial a que nos propusemos inicialmente.

Apesar da Nova Geografia Cultural trazer o conceito de paisagem como centro de grande parte de suas discussões teóricas e metodológicas, acreditamos que o conceito de espaço público oferece uma enriquecedora contribuição ao campo de análise das imagens.

1ª PARTE - As NOVAS EXPLORAÇÕES GEOGRÁFICAS

Hoje, as explorações geográficas consistem em verdadeiras metáforas das antigas. Os mundos novos são parte do nosso cotidiano, as desco- bertas são novas formas de olbar, de relacionar, de conceber; as viagens contemporâneas são constituídas pela interiorização em novos percursos temáticos. Nesse sentido, a terra incógnita não cessa de ser redescoberta. (CASTRO, 1997, p.7)

As imagens a serem exploradas pelos geógrafos hoje não são exatamente as novas paisagens que se revelam como diversas ou exóticas. Os relatórios de viagem deviam fornecer imagens como cópias acuradas do mundo. Hoje, imagens são construídas pelas mais diversas fontes e nos permitem acessar uma parte daquilo que se tece como uma trama de significados que estamos constantemente reconstruindo e que poderíamos chamar de cultura. Nessas imagens, assim como na descoberta de uma paisagem ou região, a dimensão espacial é inerente, ou melhor, basta o nosso olhar para desvelá-la.

Cosgrove e Jackson (2003), assim como nos haviam prevenido Duncan e Ley (1997), afirmam que na perspectiva contemporânea devemos desconfiar das imagens e da linguagem. Estas se transformaram, segundo eles, em enigmas. Como um desafio à noção das paisagens como sínteses aparentemente inocentes da vida humana e do mundo natural, esses autores propõem a idéia da paisagem como uma imagem cultural: "um modo de compor, estruturar e dar significado a um mundo externo".

Seu significado social é sustentado por qualidades simbólicas que revelam os significados que os grupos atribuem às áreas e lugares e que estão geralmente associados a outros aspectos e condições da existência humana. Duncan (2004, p. 109) 
converge para esta mesma perspectiva quando propõe como "foco de atenção a maneira como a paisagem reproduz códigos de significação que estão presentes em outras áreas do sistema cultural" (DUNCAN, 2004, p.109). Ampliam-se as fontes disponíveis para a geografia cultural: as relações entre as paisagens - como configurações de símbolos e signos - e as suas representações simbólicas ou icônicas estariam, portanto, na pauta dos geógrafos culturais.

A elaboração de um filme envolve um tipo de imaginação geográfica mais ou menos consciente, que certamente participa de uma mensagem. Tuan (1991) nos traz duas proposições que serão aqui de grande utilidade. Para que a o discurso seja considerado parte integral da construção e do entendimento do lugar pelo geógrafo, o autor defende o exame da variedade de materiais lingüísticos existentes. Em outro artigo, intitulado "Thought and Landscape", ele nos explica como é possível atribuir um rico significado à imagem: "Pode ser o ambiente desenhado por um arquiteto, um primoroso ensaio descritivo de paisagem, ou podem ser as palavras de um professor, no esforço de apreender o espírito do lugar na sala de aula e em campo" (TUAN, 1979, p. 97).

A abordagem iconográfica de Daniels e Cosgrove (1998, p. 1-2) defende o status da paisagem "como uma imagem cultural composta por símbolos $(\ldots)^{\prime \prime}$. É nesse sentido que o modelo etnográfico da iconografia da história da arte tem sido recentemente adotado por geógrafos que querem dar maior ênfase às imagens na análise da representação da paisagem.

Este tipo de interpretação operaria através de dois processos que se qualificam e ratificam mutu- amente: a experiência estética intuitiva da obra e a pesquisa arqueológica racional. Não são processos que se sucedem, mas que servem de base um ao outro. Caberia ao profissional separar, tanto quanto possível, a experiência recriativa (que depende da sensibilidade natural e da bagagem cultural do espectador) dos valores intencionais do artista. No entanto essa separação não é tão fácil quanto se supõe. Assim, a dimensão subjetiva encontrase inerente ao nosso empreendimento, a ser confrontada com outros textos ou documentos.

Panofsky (2001) nos fala que se trata de um processo orgânico e indivisível de abordagem de um mesmo fenômeno que é a obra de arte como um todo. Nesse fenômeno distinguimos três domínios ou camadas de tema. O primeiro seria o domínio pré-iconográfico no qual descobrimos como objetos e fatos específicos foram representados por determinadas formas, revelando o tema primário da obra. O segundo é o iconográfico, em que se descobre como temas específicos foram representados por determinados objetos e fatos, sendo relativo à idéia ou tema convencional.

Finalmente, o domínio iconológico é aquele relativo ao conteúdo intrínseco. Nele interpretamos como tendências gerais e essenciais da mente humana foram representadas através de temas e conceitos específicos. Em todas essas "etapas", o processo de identificação e interpretação depende da correção do nosso equipamento subjetivo pela nossa compreensão dos diferentes processos históricos envolvidos.

É importante ressaltar que Costa (2003) nos lembra que o espaço fílmico não é uma documentação objetiva ou neutra da realidade, mas sim ideologicamente carregada. Nesse sentido cabe a 
busca do conteúdo proposta por Panofsky (2001) como sendo aquilo que a obra denuncia, mas não ostenta. Esse trabalho da iconologia se difere da simples descrição e classificação. É importante ressaltar essa distinção se queremos estar atentos aos perigos de se tratarem materiais literários ou artísticos com ingenuidade ou superficialidade.

Uma atitude que se revela tão importante quanto esta, trazida pela antropologia, é reconhecer que o objeto de estudo não é o estudo ou texto científico. Como propõe Geertz (1989), é necessário ao etnógrafo situar-se e ter o entendimento dos textos antropológicos como ficções; não que sejam falsas ou não-factuais, mas no sentido de que são algo construído, modelado. Alinha-se a Panofsky (2001) que afirmou que o historiador de arte, diferentemente do observador "ingênuo", sabe que sua "bagagem" cultural contribui para o objeto de sua experiência.

As posições de ambos os autores indicam sua proximidade de um projeto fenomenológico que questiona tanto a observação indutiva e a simples descrição que esta adota, quanto a dedução e a demonstração a partir de modelos lógicos que por simplificação poderiam dar conta da generalidade dos objetos ou fenômenos que se procura explicar. Isso possibilita um diálogo com teóricos da Nova Geografia Cultural afinados com uma postura interpretativa. Aqui, nos posicionaríamos de maneira semelhante em relação a nosso objeto de estudo. Partimos de diversos pontos de vista, do autor, de outros críticos de cinema, de geógrafos que interpretaram imagens fílmicas, assim como do nosso próprio ponto de vista. De fato, a partir desse diálogo construímos nosso próprio objeto.

No que diz respeito ao conceito de cultura considerado, ele será visto a partir de três critéri- os gerais propostos por Hoefle (1998). Estes tratam da abrangência fenomenal do conceito às diferentes esferas sociais, da importância atribuída à cultura como fato explicativo do comportamento humano, e dos modelos de processos de mudança cultural. Nos aproximamos do conceito de cultura de Geertz (1989) de modo que se considera a cultura como uma esfera da vida, que não estabelece relação determinante com a sociedade, a política ou a economia. Utiliza-se a imagem de "teia de significados". Sua visão seria abrangente já que a cultura é constituída pela relação entre as diferentes esferas da vida. No que diz respeito aos processos de mudança cultural, estes são entendidos a partir de uma visão historicista próxima da fenomenologia.

\section{A ANÁLISE SEMIOLÓGICA}

Em seu livro, Martine Joly nos diz que seu objetivo é o de ajudar a compreender a maneira como a imagem comunica e transmite mensagens. Podemos repetir que não deixa de ser válida como justificativa para esse trabalho a idéia de que, se hoje muitos defendem que vivemos em uma civilização da imagem (Medeiros, 1999), por outro lado, há uma tendência a certa leitura natural dessa imagem. Esta, está na verdade, está permeada por convenções, história e cultura mais ou menos interiorizadas em nós, que ela tem a capacidade de ativar (Joly, 1999). A abordagem de Joly fundamenta-se na semiologia de linha francesa de Roland Barthes, que considera a imagem, assim como o padrão geral da língua, como composta por signos constituídos por um significado e um significante. Através de códigos, esses signos podem apresentar mensagens plásticas, icônicas ou lingüísticas. 
Quando entramos nesse campo que trabalha com imagens, é preciso dar conta da complexidade do termo - que se situa entre imitação da realidade, traço dessa realidade e convenção. Análogas da realidade, elas são ícones perfeitos. Porém, sua força de persuasão provém de seu aspecto de índice, que é o que provoca o esquecimento de seu caráter representativo. No entanto, ainda, se essas representações são compreendidas é porque existe, entre as pessoas que as fabricam e seus receptores, um mínimo de convenção sociocultural. Ou seja, as imagens que, pelo seu caráter de semelhança, se apresentam como ícones perfeitos, devem boa parcela de significação a seu aspecto de símbolo. O termo imagem pode também possuir variadas interpretações segundo diferentes autores, em diferentes momentos. A definição que consideraremos aqui, proposta pela autora, seria a de um objeto segundo com relação a um outro que ela representa de acordo com certas leis particulares (Joly, 1999). Ele pode constituir, simultaneamente, um ícone, índice ou símbolo.

A relação que existe entre imagem e linguagem é aqui de fundamental importância para nós. Joly defende a complementaridade entre imagem e linguagem. Na verdade entre ambas há uma circularidade: uma é reflexo da outra ao mesmo tempo em que cria novos sentidos para a outra. Assim a mensagem lingüística e a mensagem visual não devem ser consideradas separadamente.

Barthes (1982) nos propõe que a linguagem pode desempenhar a função de ancoragem bem como de ligação. Na primeira função, ela ancora a gama de possibilidades de sentidos denotativos e conotativos, guiando assim a identificação e a interpretação. Já a ligação pressupõe uma relação complementar entre fala e imagem em que ambas são como fragmentos de um sintagma mais geral. Sua unidade se faz a um nível superior da história da diegese ou da anedota. Para Barthes, é o caso do cinema onde a fala não é simples elucidação; ela expressa sentidos que não estavam presentes na ação e faz a ação avançar.

A seguir, levantaremos alguns pontos trazidos por Joly que acreditamos serem mais pertinentes ao nosso trabalho. Primeiramente, ela nos adverte sobre três questões principais que devemos ter em mente ao iniciar a análise de uma imagem. A primeira delas diz respeito aos nossos objetivos. Uma análise não deve ser feita por si mesma, mas a serviço de um propósito consciente. É isto que irá nos permitir instalar nossas próprias ferramentas que irão determinar em grande parte nosso objeto de análise e suas conclusões. Na medida em que não há um método absoluto de análise, deve haver um processo de construção dessa metodologia.

A segunda questão, que se relaciona com a primeira, trata das precauções que devemos tomar em separar, na nossa interpretação, aquilo que é pessoal do que é coletivo. Para buscar o que uma mensagem provoca de significado aqui e agora, é necessário ter limites e pontos de referência do contexto histórico de seu surgimento e de outras interpretações. Nesse ponto Joly (1999) dialoga com nossas referências a Panofsky (2001) e a Geertz (1989).

A terceira questão envolve a consideração do contexto e das funções dessa imagem. Isso significa saber em que condições ela foi produzida, o contexto específico de seu autor e do seu recebimento pelo público. Devemos também considerar as funções que supostamente lhe foram desig- 
nadas. Ou seja, para quem ela foi produzida? $\mathrm{Ou}-$ tra perspectiva associa a imagem à comunicação e sua funções colocando-nos que ela é não apenas expressiva. A função comunicativa de uma mensagem visual determina com força sua significação, de modo que não se pode considerá-la somente do ponto de vista da experiência estética da obra de arte que vale apenas por si mesma.

Finalmente, ao falar sobre as possibilidades que traz e a função que pode desempenhar a análise semiológica da imagem, Joly (1999, p. 48) afirma:

\section{"Demonstrar que a imagem é de fato uma lin-} guagem, uma linguagem específica e beterogênea, que nessa qualidade, distingue-se do mundo real e que, por meio de signos particulares dele, propõe uma representação escolbida e necessariamente orientada, distinguir as principais ferramentas dessa linguagem e o que sua ausência ou sua presença significam, relativizar sua própria interpretação, ao mesmo tempo em que se compreendem seus fundamentos (...)".

Esta parece ser uma tarefa trabalhosa que se abre também para nós geógrafos e que aqui aceitamos. É nesse sentido que procuramos proceder à análise das imagens de "O signo do leão", filme de Eric Rohmer.

Jimenez, da escola de arquitetura da Bretanha (Rennes), nos propõe uma análise do filme "Calle Mayor" do ponto de vista da antropologia urbana e da história, tendo como ferramenta a idéia de mentalidade e imaginário social. Sua preocupação com o espaço construído pelo filme é central. O título de seu artigo já nos anuncia que ele fará uma leitura da construção cinematográfica de um espa- ço urbano. Trata-se de uma investida antropológica que caminha no sentido da interdisciplinaridade. Por um lado, encara o espaço urbano na sua estrutura material e histórica e suas resultantes ideais. Por outro, assume a problemática da representação cinematográfica da cidade tendo como referentes a morfologia urbana e o momento cultural. Para o autor, o imaginário da cidade ainda é domínio pouco explorado dentro de uma perspectiva que relacione formas urbanas e indivíduos em função de uma estrutura social ou de um conjunto ideal.

Ele também nos apresenta dualidades. O imaginário poderia ser definido como a relação do indivíduo com a representação que ele se faz do mundo. É a expressão e a re-presentação do real existente e visível. O real participa da criação da ficção assim como a ficção determina as transformações do real. A segunda dualidade existe entre as formas físicas (do espaço e arquitetura) e o imaginário. De um lado podemos ver o papel da estrutura urbana na conformação do imaginário, do outro a maneira como o seu significado depende da nossa percepção e das transformações operadas pelo imaginário.

Trata-se de uma importante contribuição de outro campo disciplinar para nossa análise do filme de Rohmer, na medida em que valoriza a espacialidade no cinema e traz a relevância desse tipo de estudo.

\section{2 a Parte- Contextualização da Obra e Diretor}

Eric Rohmer figura, ao lado dos nomes de Claude Chabrol, Jaques Rivette, Jean-Luc Godard et François Truffaut, como um dos representantes do movimento de cinema francês chamado Nouvelle Vague (Nova Onda), que surge na França no final 
da década de cinqüenta e início da década de sessenta. Além de uma nova estética que se coloca em função de uma mudança profunda no mundo da produção marcada por baixos custos, esses diretores irão criar o chamado cinema dos autores (cinéma des auteurs).

A idéia do cineasta como autor fora lançada teoricamente por esses mesmos nomes, então redatores da revista Cabiers du Cinéma, no sentido de distinguir alguns cineastas americanos e favorecer o reconhecimento do cinema como uma arte, completa e à parte. Vindos da crítica, foram eles que testaram pragmaticamente essas idéias. Significava que o diretor ultrapassa seu papel de chefe de equipe para colocarse como o autor de um romance - que inventou uma história e pode ele próprio contá-la e afirmar, de filme em filme, tanto uma temática como um estilo. Ou seja, aquele que impõe um olhar.

O tom era de total ruptura com o estilo do cinema francês dos anos 50. A utilização de atores desconhecidos, cenários reais, realismo do diálogo e das situações e nova gramática técnica, implicavam na verdade uma verdadeira revolução estética. Entretanto, todas essas mudanças não poderiam ter-se realizado em qualquer contexto. No final da década de 1950 o adjetivo de "novo" era usado em muitas outras áreas. É quando se afirmam o novo romance e o novo realismo, mostrando que o campo das artes legítimas também estava sendo sacudido.

$\mathrm{Na}$ esfera da política, na França se dava o agravamento do conflito algeriano e Jean-Paul Sartre rompia com o PCF após a intervenção soviética na Hungria. Sentiam-se os ecos do XX Congresso do Partido Comunista que em 1956 condenava o stalinismo. Prédal (1996) não hesita em colocar a Nouvelle Vague como sendo fruto desse clima que culminou na França com a V República. A cultura substituía então o colonialismo. O general De Gaulle e seu ministro da cultura, André Malraux, viam no cinema uma contribuição à grandeza do país. Eles acreditavam na maior eficácia em se proteger o país pela sua hegemonia cultural que pela sua potência econômica ou força militar.

Ainda, determinadas condições estavam reunidas ali para que houvesse um novo público receptor desse novo tipo de cinema. É justamente por volta da década de 50 que se afirmam os movimentos dos cine-clubs e revistas de cinema, que descobriam Orson Welles, Eisentein, Carl Dreyer ou o expressionismo alemão. O público tornavase assim mais exigente questionando principalmente a qualidade da produção nacional. Mesmo na televisão francesa, surgia o interesse por uma obra que não se julga tanto mais pela precisão de uma gravação, a modelagem de uma iluminação, o luxo de um cenário, nem a nobreza de um diálogo, mas pela verdade no tom, pela justeza de um olhar e pela ousadia de um movimento traçado em plena rua com uma câmera 16mm na mão (Prédal, 1996).

Assim, entre os diversos componentes que ajudam a conformar a noção de Nouvelle Vague, a dimensão econômica foi fundamental. Em Rohmer essa característica apresenta-se de modo singular. Após o lançamento de seu vigésimo quarto longa metragem, em uma edição de 2004 da revista Cabiers du Cinéma que lhe foi dedicada, assinala-se a maneira como a economia de seu cinema é dotada de sentido de equilíbrio entre metas artísticas e meios materiais, criando e mantendo a independência estética do autor. São essas e outras particularidades que procuraremos explorar mais adiante. 
ROHMER: CRÍTICO E DIRETOR DE CINEMA

O que mais impressiona Rohmer é o domínio ou controle do espaço, ou seja, a capacidade do cineasta de saber organizar o espaço do filme rigorosa e inventivamente. Para o autor, há três tipos de espaço, correspondendo a três modos de percepção do espectador e três procedimentos distintos do cineasta. O primeiro deles seria o espaço pictórico, de modo que cada enquadramento possuiria o "fechamento" de um quadro, constituindo assim uma espécie de pintura "possível". Dentro deste quadro, a relação espacial entre as figuras corrobora o seu significado tanto quanto a sua semelhança a um objeto usual.

O segundo tipo descrito é o espaço arquitetônico - o cenário. O papel desse espaço arquitetônico manifesta-se no exercício da encenação (miseen-scène). "Todos esses lugares não se apresentam unicamente como quadro de ação, seu receptáculo. Eles pesam sobre as atitudes dos personagens, direcionam seu jogo, ditam seus deslocamentos" (Rohmer, 2000, p.15). Neste trabalho que resultada de sua tese de doutorado sobre a adaptação de "Fausto" de Murnau, Rohmer chega inclusive a falar da "geografia dos filmes de Murnau". Por último, há o espaço fílmico que dos meios de que o cineasta dispõe para nos apresentar um espaço dinâmico. Ou seja, é aquele que surge do corte e da montagem, e que se forma na mente do espectador.

Segundo o autor, Murnau postula através da sua montagem, mais do que o realismo do espaço, a afirmação de sua primazia, na medida em que as relações espaciais têm primazia sobre as temporais. As descrições de Rohmer sobre o filme de Murnau nos remetem a uma idéia central quando desejamos compreender os fenômenos do ponto de vista de sua dimensão espacial ou geográfica: a necessária relação entre a disposição espacial dos objetos e as ações. Trata-se mesmo de uma idéia cara à ciência geográfica e fundamentada por Milton Santos (2002) quando define a geografia como uma ciência do espaço e o espaço como sistema de objetos e ações. Para ele, o espaço é uma forma-conteúdo: uma forma que não tem existência empírica e filosófica se a considerarmos separadamente do conteúdo; um conteúdo que não poderia existir sem a forma que o abrigou.

Ao mesmo tempo, a compreensão de Rohmer sobre as imagens de Murnau nos remete a uma possível compreensão das imagens produzidas por Rohmer em seus filmes e as relações que ele procura com o espaço. Este tampouco parece deixar estas relações soltas ao acaso.

Em um artigo intitulado "Paris vu par Eric Rohmer", Frédéric Bas nos aproxima um pouco da abordagem de Rohmer ao falar da relação que o diretor estabelece com Paris através de seus filmes. "A capital é a Cidade com letra maiúscula de onde partem todas as histórias, onde começam e acabam todas as aventuras" (Bas, 2005, p.1). Para Bas, o realismo de Rohmer liga-se, ao mesmo tempo, a uma Paris-cenário (Paris-décor), que traz o traçado exato das ruas, e a uma Paris-experiência (Paris-expérience) dos afetos e sentimentos dos homens. Ele identifica assim uma maneira chave de compreender grande parte da obra do diretor e sua relação com essa cidade. Rohmer interessar-se-ia pela cidade sob dois aspectos complementares.

Primeiramente, trata-se da sua representação exata como forma fixa; é a cidade dos arquitetos, histórica, com suas ruas e muros de pedra. Uma relação de exatidão documentária em que o realismo aparece como condição primeira a uma boa 
representação da cidade. No entanto, esta é indissociável de uma tomada da cidade como sistema vivo, uma circulação constante dos homens, um reservatório ativo de signos e afetos, de falas, de grandes e pequenas ações. Esta seria a Paris do parisiense, do passante, do pedestre.

Bas nos mostra também como essa dupla visão está particularmente clara no filme que será objeto de nossa análise nesse trabalho. Em "O signo de leão" seu personagem principal é mergulhado nessa Paris capital, onde seu personagem se perde e se degrada progressivamente. A câmera de Rohmer nos oferece dois pontos de vista dessa trama. Um do alto e outro do mergulho (plongée) nas profundezas do tecido urbano. Acreditamos que agora é possível passar à nossa busca interpretativa propriamente dita e à terceira parte.

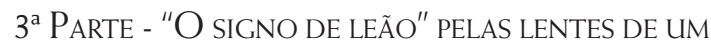 GEÓGRAFO}

Assim como indica a análise semiológica, também estaremos em busca das mensagens presentes na imagem através de seus sistemas de signos. Como sabemos, estes são constituídos por um significado que cumpre uma função denotativa e um significante que cumpre uma função conotativa. Joly, baseada no trabalho de Roland Barthes, propõe três tipos de signos: os plásticos, os icônicos e os lingüísticos. $\mathrm{O}$ plástico refere-se às cores, à textura e à luz. O signo icônico refere-se ao contexto, é o nosso mundo contextual, o chamado referencial. O lingüístico, no caso do filme, refere-se ao título e aos diálogos, evocando toda a relação que as palavras mantêm com a linguagem da imagem. Na realidade, esses signos encontram-se, na maioria das vezes, superpostos e suas mensagens entremeadas.
Os códigos visuais utilizados pelo cinema para nos transmitir mensagens através de signos são infinitamente variáveis. Entre eles poderíamos ressaltar o gestual, o cenográfico, o cromático, o fotográfico ou pictórico que inclui os diferentes ângulos de filmagem, o enquadramento e a composição, a iluminação, o figurino e até a trucagem. Estaremos analisando as imagens que seguem em busca das mensagens escritas pelo diretor através destes diferentes códigos cinematográficos.

Foi necessário selecionar algumas imagens para a análise. Buscávamos aqueles enquadramentos em que era mais importante a relação do personagem com seu contexto. Ou seja, quando a sua inserção no espaço era fundamental para desvendar seu estado físico e sentimental, sua trajetória, ou quando a cena nos apresentava Paris e a relação de seus espaços públicos e de seus lugares simbólicos com a dinâmica da vida de seus personagens.

Os espaços públicos, como são aqui entendidos, são aqueles espaços que fundam a vida pública e garantem a sua reprodução. É o espaço do encontro com o diferente, do reconhecimento das identidades, da atualização do pacto social, e por essência, é o espaço da visibilidade onde somos todos atores e simultaneamente espectadores. Trabalhamos com esse conceito a partir de sua tripla dimensão. Uma física ou morfológica refere-se ao arranjo espacial; a outra, comportamental, referese às ações e atitudes que lhe conferem existência; a terceira é simbólica e dá conta de toda a rede de valores e significados que são codificados nas praças, ruas, monumentos e calçadas de uma cidade.

Le Signe du Lion foi filmado em preto e branco em 1959 com uma câmera 16 mm. Narra a história de um músico boêmio de nacionalidade austríaca, que 
se vê despejado e lançado nas ruas e cujo percurso de declínio pessoal e social iremos acompanhar progressivamente através da câmera de Rohmer. Tudo se passa no real cenário da cidade de Paris, entre os protagonistas da cena do bairro de artistas, jornalistas e intelectuais de Saint-Germain des Prés. A maioria das cenas é filmada nos espaços abertos de Paris, o que, acreditamos, valoriza especialmente os espaços públicos e as dinâmicas que ali se desenrolam cotidianamente. Através de encontros e desencontros, festas públicas, pequenos dramas, pequenos espetáculos e conflitos, a cena pública de Paris nos é apresentada através da ótica de Rohmer, ao seguir o destino de seu personagem.

É verão e em Paris todos estão de férias. $\mathrm{Na}$ espera de uma herança que nunca chega, Pierre Wersselin recusa-se a trabalhar e vive precisando fazer empréstimos a quem ele conhece. Mas as primeiras imagens que nos são apresentadas desse personagem na cidade mostram um homem que bem ou mal possui um círculo de relações e circula pelos pontos e bares de Saint-Germain des Prés com conforto e familiaridade.

No primeiro fotograma selecionado, identificamos primeiramente uma cena típica de um grupo que se encontra e se senta na varanda de um café para tomar uma bebida e fumar cigarros, enquanto conversam. O figurino indica a elegância dos personagens, principalmente do personagem principal que veste uma boina e se encontra acompanhado de uma moça. Ele está no centro da mesa e tem a atenção da moça totalmente voltada para si nesse momento. É o começo do filme e ele pensa que é o herdeiro de uma fortuna que mudará sua vida. Em sua conversa, eles estão na realidade planejando a grande festa que ele deseja realizar em seu aparta- mento, quando um deles interpela dizendo que será difícil encontrar alguém na cidade, pois nessa época em Paris só restam os mendigos.

Esta cena entra em oposição com uma cena em outro ponto da narrativa em que a figura de Pierre já se encontra próxima à famosa figura do clochard ou do mendigo. Após a festa, Pierre descobre que foi deserdado e que está despejado de seu apartamento. No segundo fotograma, Pierre encontrase não mais ao centro, mas no último plano, no canto esquerdo da imagem. Do fundo ele simplesmente observa a cena pública de muitos homens bem vestidos, sentados na varanda do café, bebendo e comendo, e divertindo-se com o centro propriamente dito da cena. Vemos um garçom que põe um mendigo para fora do estabelecimento com um jato de água. A postura de Pierre aí é completamente outra; suas costas estão curvadas, os braços apoiados nas pernas; suas roupas sujas e amassadas indicam já seu cansaço e o tempo em que ele já está na rua, afastado desse outro lado que ele agora observa. A câmera mais uma vez encontrase na posição de um observador distante que passa e é capaz de ver o que se passa ali.

No terceiro fotograma Pierre passa em primeiro plano no canto esquerdo, mas nosso olhar dirige-se para o centro da imagem, que é a imponente construção do Panthéon de Paris. Esse monumento é um dos pontos centrais que nos é oferecido, nos permitindo traçar um mapa mental do percurso de Pierre pela cidade. Pierre então passa como um transeunte qualquer, por esse espaço público amplo, dos grandes monumentos, das ruas largas, dos carros e da circulação. A câmera é a do plano de conjunto que captura os prédios e construções da cidade em movimento. 
O momento desses próximos fotogramas é fundamental, pois é quando a câmera está baixa e assim desloca o nosso olhar para outra escala da cidade. A quinta imagem nos faz olhar para a calçada, para o seu canto e seu piso sujo. Abaixo da altura do nosso olhar, e na altura dos pés do nosso personagem central, há um homem que dorme sobre folhas de jornal. Em oposição a essa grande cidade histórica, dos monumentos imponentes, somos levados a conhecer uma outra dimensão desse espaço urbano. Se na outra escala, a cena de alguém que dorme no canto da calçada pode passar desapercebida, na pequena escala somos levados a observar esse fato. Aí, Pierre ainda encontra-se distante dessa realidade, mas já somos capazes de vê-la. $\mathrm{Na}$ verdade, progressivamente vão aparecendo algumas dessas figuras do mendigo ao longo da trajetória do personagem (quarto fotograma), porém agora (quinto fotograma) a câmera se detém um pouco mais de tempo sobre ela, e Pierre passa ao mesmo tempo um pouco mais próximo também.

Ao traçar seu destino pelas ruas de Paris na busca de algum conhecido e de alguma ajuda, a única coisa que ele encontra são portas fechadas, pessoas que estão partindo de férias ou que não podem ajudá-lo. Ele inicia sua trajetória passando desapercebido entre os outros pedestres. Perdendose no meio dessa Paris, ela transforma-se para ele em uma espécie de labirinto. Aos poucos, ele passa a ser percebido, porém de uma outra maneira. Pierre passa a ser reconhecido como mais um daqueles mendigos que às vezes chamam a atenção das pessoas na rua.

Agora, estamos diante de mais um cartão postal da cidade. Esta é a nossa sexta imagem. À beira do
Rio Sena, dois turistas americanos, uma jovem loira e um homem cujo relógio de pulso se pode ver, falam sobre como estão cansados e com fome e que já está na hora de voltar para casa. Já encontrando dificuldades para alimentar-se, após ter sido barrado na porta do hotel onde ele devia sua diária, $\mathrm{Pi}$ erre estava nesse momento caminhando errante até se deparar com o fim do trajeto e ter que virar as costas. O plano anterior a este é o do muro de pedras com uma porta de madeira que domina inteiramente o quadro, aparecendo enorme e pesada diante do olhar já perdido e cansado Pierre. De cabeça baixa ele, ele retorna então, passando pelo jovem casal que se prepara para retornar ao hotel.

É interessante notar como o rio Sena, signo que geralmente emite uma mensagem que remete ao amor romântico, a férias e lua mel em Paris, a piquenique de verão, então se transforma em mais um lugar que assinala a decadência de Pierre. As suas águas, que recebem o reflexo do sol, são para ele embriagantes, deixando-o tonto. Assim, os significados atrelados a esse lugar começam a se apresentar para nós de maneira diferente na medida em que passamos a enxergá-lo sob a ótica de um outro tipo de ator da cidade.

A sequência de três planos a seguir (sétimo, oitavo e nono fotogramas) nos oferece uma visão do Rio Sena visto a partir de três escalas diferenciadas. Na primeira, podemos ver esse homem abandonado à beira do rio, que dorme em pleno dia, com a cabeça apoiada sobre a pedra, vestindo um terno, sem sapatos, calçando apenas meias furadas. Há uma linha diagonal que corta a imagem, separando a parte escura da água, a parte mais clara da pedra e a parte cinza do asfalto. Ele é o único personagem presente nessa cena, o que nos 
passa a sensação de ele estar só, apesar de sabermos que está em plena cidade de Paris. Na imagem seguinte temos o ponto de vista de alguém que observaria do alto, do outro lado da rua provavelmente. Aí já podemos inserir Pierre melhor no contexto em que ele se encontra. Aparece como um homem que dorme no meio de um espaço público da cidade, e que é visto por um outro personagem em cena.

$\mathrm{Na}$ próxima, temos um distanciamento radical de Pierre. Este mesmo lugar é inserido em sua escala seguinte, na qual Pierre desaparece no meio dessa cidade cortada por ruas e vias. O rio aparece também como uma linha transversal na parte inferior da imagem, cortando a cidade, ligado por pontes. É a cidade da circulação, das grandes construções, dos parques; aquela que vê o planejador urbano, ou que se pode ver de um helicóptero.

Toda a trajetória de degradação pessoal de Pierre na verdade tem uma inserção espacial precisa, que Rohmer nos permite lembrar e localizar. Alguns podem aos poucos identificar os grandes pontos de referência da cidade dos monumentos históricos, das grandes universidades ou dos grandes bulevares que estão mais ou menos presentes no nosso mapa mental da cidade. No décimo fotograma, o palco da cidade pode ser reconhecido. A encenação desses dois clochards tem como cenário a lateral da Catedral de Notre-Dame de Paris.

Duas imagens que iremos descrever agora são significativas da invisibilidade de Pierre nessa grande cidade, diante seus amigos anteriores. No fotograma onze, podemos ver, em primeiro plano, Pierre, de costas para a câmera, de forma que seu rosto não possa ser visto, sentado em um carrinho que está sendo puxado por um outro perso- nagem. Este personagem tem, em seu figurino sujo e mal cuidado, sua expressão corporal, sua face barbada, com um cigarro preso à boca, todos os códigos que nos passam a mensagem do típico mendigo. Em contra-plano (fotograma doze) podemos ver dentro de um carro conversível o casal de amigos de Pierre. A moça loira aponta para os dois que lhe chamaram a atenção e causaram riso e os mostra ao seu namorado, amigo de Pierre. Nesse momento o "mendigo" pergunta se eles não querem levá-los para dar uma volta no seu carro. $\mathrm{O}$ amigo de Pierre tem o braço ao longo da moça como quem quisesse protegê-la. Eles terminam por ir embora dizendo ter horror à cena.

O irônico é que o enredo termina quando Pierre é encontrado por esse mesmo casal, que o salva no momento em que ele já quase perdia sua sanidade plena. Por um acaso do destino ele recebera a herança e estava sendo procurado. Neste mesmo carro, o casal o leva embora sob flashes de jornalistas que descobriram quem era o herdeiro desaparecido de uma incrível fortuna. Nesta última imagem (décimo terceiro fotograma), podemos ver em primeiro plano, à direita, as lentes da câmera do jornalista que deseja filmá-lo e entrevistá-lo. Ao centro da imagem temos a mão de Pierre que acena para a câmera desejando aparecer para ela. Do lado esquerdo da imagem temos dois braços que o carregam. Do seu lado esquerdo encontra-se seu amigo e de seu lado direito sua namorada que aparecem na figura anterior. Em último plano, pode-se reconhecer, sobretudo pelo figurino com o casaco quadriculado e o mesmo chapéu, seu amigo clochard que acabara de ser deixado para trás por Pierre. 


\section{CONSIDERAÇÕES FinAIS}

A câmera de Rohmer nos apresenta um espaço público que é ao mesmo tempo da publicidade e da invisibilidade. Nele podemos estar em evidência ou "invisíveis" no papel de um mendigo "qualquer" da grande cidade. É portanto o espaço do encontro, previsto ou fruto do acaso, e do desencontro na imensidão de ruas, pessoas e possibilidades que oferece. Nela, podemos estar no palco - sentados na varanda de um café, sendo observados por quem passa - e ao mesmo tempo sermos platéia, de um espetáculo momentâneo que se cria na calçada. Paris nos é assim mostrada em toda sua magnificência, do Rio Sena ao Panthéon. Mas ela pode ser também ruidosa demais, suja demais e áspera demais. Nela podemos estar sempre acompanhados do ritmo dos passantes, ou isolados na solidão de um canto vazio.

Assim, podemos nos sentir nela incluídos - em seus espaços e em seu ritmo - ou excluídos - de determinados lugares e momentos. Esse espaço público é portanto onde se trava a dinâmica da vida pública, que se constitui pelo diálogo e pelo conflito. O que é considerado desejável ou não em determinado espaço será fruto de um confronto de interesses. Nos diferentes tipos de espaço público, agregam-se grupos e agregam-se valores simbólicos. A identidade e a diversidade encontram-se aí representadas. Todos estes são pares (visibilidade/invisibilidade, diálogo/conflito, inclusão/exclusão e etc.) construídos através de uma morfologia, das ações e do imaginário simbólico. Revelam-nos e ajudam a recriar uma cultura.

Aqui, não se tratava de uma descrição objetiva, mas sim de uma interpretação possível. Algo que se deve ressaltar é que nessa busca a metodologia foi construída ao longo do percurso, tendo como ferramentas os princípios norteadores da semiologia e o conceito geográfico de espaço público que particulariza nossa análise.

As mensagens que encontramos nos códigos elaborados por Rohmer são mensagens que, em grande medida, dialogam com o discurso geográfico. Elas nos liberam uma série de significados presentes nas geografias concretas dos lugares e espaços públicos de Paris, bem como questionam alguns significados que carregamos presentes em nosso imaginário. O tratamento do espaço pelo diretor no filme mostrou-se portanto extremante fértil à análise. As possibilidades de leitura da imagem como signo construído sobre os diferentes eixos plástico, icônico e linguístico são amplas e viabilizam uma aproximação simultaneamente crítica e interdisciplinar da imagem.

Esse trabalho não consiste certamente no encontro de uma mensagem pré-existente no filme. Procuramos compreender o modo de significação do filme enquanto meio de expressão e comunicação - que diz respeito não apenas a uma maneira de entender o mundo e se relacionar com ele, como a uma concepção sobre a dimensão espacial da vida urbana. Podemos dizer que essas imagens expressam e comunicam um determinado imaginário sobre a cidade, seus personagens, trajetos, hábitos e lugares privilegiados.

\section{REFERÊNCIAS BIBLIOGRÁFICAS}

BARTHES, Roland. Essais critiques III. Rbétorique de l'image. L'obvie et l'obtus. Paris: Éditions du seuil, 1982.

BAS, Frédéric. Paris vu par Eric Robmer. In: Forum de images, hors, abril, 2005.

COSTA, M. H. B. V. Cinematic Cities: Researching Film as Geographical Texts. In: Pyrs Gruffudd et all. (org.). Cultural Geograpby in Practice. Londres: Edward Arnold Limited, 2003.

Cabiers du Cinéma. Spécial Rohmer, março, 2004. 
COSGROVE, D. e DANIELS, S. (orgs.) Introduction: iconography and landscape. In: The iconograpby of landscape. Cambridge: Cambridge University Press, 1998.

COSGROVE, D. e JACKSON, P. Novos Rumos da Geografia Cultural. In: Introdução à Geografia Cultural. Rio de Janeiro Bertrand Brasil, 2003.

DUNCAN, J. e LEY, D. (ed.) Introduction. Representing the place of culture. In: Place/Culture/Representation. Londres: Routledge, 1997.

GEERTZ, C. Uma Descrição Densa: Por uma teoria interpretativa de cultura. In: A Interpretação das Culturas. Rio de janeiro: LCT, 1989.

GOMES, P. C. C. A Condição Urbana - Ensaios de Geopolítica da Cidade. Rio de Janeiro: Bertrand Brasil, 2002.

HOEFLE, S. W. Cultura na história do pensamento cientifico. In: Revista de Pós-Graduação em Geografia, 2, p.6-29, 1998.

JIMENEZ, Floréal. Calle Mayor, construction cinématographique d'un espace urbain et d'une structure idéologique et sociale. In: Espaces et sociétés, Université Paris Descartes - CNRS, Paris, $n^{\circ}$ 3, 1996

JOLY, Martine. Introdução à Análise da Imagem. Campinas: Papirus editora, 1999.

MEDEIROS, Rogério. Signos e representações. Apontamentos sobre um estudo da imagem. In: Anais do $6^{\circ}$ Encontro de mestrado em História da Arte EBA/UFRJ, dezembro, 1999.

PANOFSKY, E. Significado nas artes visuais. São Paulo: Perspectiva, 2001.

PRÉDAL, R. 50 ans de cinéma français. Paris: Nathan, 1996. ROHMER, E. L'organization de l'espace dans le faust de Murnau. Paris: Petite bibliothèque Cahiers du Cinéma, 2000.

SANTOS, Milton. A Natureza do Espaço. Edusp: São Paulo, 2002.

TUAN, Y. Thought and Landscape. The Eye and the Mind's Eye. In: MEINING, D., JACKSON, J. et all. (ed.) The Interpretation of ordinary landscapes. Geographical Essays. Oxford: Oxford University Press, 1979.

\section{ABSTRACT}

THE PURPOSE OF thIS ARTICLE IS TO EXPLORE THE POSSIBLE RELATIONSHIPS BETWEEN GEOGRAPHY AND CINEMA IMAGES. WITH A SPECIAL FOCUS ON THE REPRESENTATION OF THE CITY, THIS STUDY AIMS TO ANALYZE THE ROLE OF PUBLIC SPACES ON THE FILM "LE SIGNE DU LION", BY ERIC ROHMER. AS THIS FRENCH DIRECTOR CHOOSES TO FILM THE EVERY-DAY-LIFE OF THE PARISIAN STREETS, PLACES AND CAFÉS IN 1959, HE DEPICTS A VIEW OF THE CITY THAT ALLOWS US TO EXPLORE SOME ASPECTS OF URBAN LIFE. ALTHOUGH PUBLIC SPACE CONCEPT IS FREQUENTLY USED BY URBAN AND POLITICAL GEOGRAPHY, IT CAN BE CONSIDERED IN ITS SYMBOLICAL DIMENSION AS WELL, WICH IS USEFUL TO CULtURAL GEOGRAPHY INTERESTED ON THE INTERPRETATION OF URBAN UNIVERSE. THE INTENTION HERE, INSTEAD OF REVEALING THE ORIGINAL DIRECTOR'S PURPOSE, IS TO BRING A SPECIFIC PERSPECTIVE OF THE FILM, CONSIDERING CINEMA NOT ONLY AS A WAY OF SEEING THE WORLD, BUT AS A PARTICULAR VIEW OF URBAN LIFE SPATIALITY. KEY WORDS: CINEMA, PUBLIC SPACE, IMAGE, SIGN, INTERPRETATION. 